\title{
Screening, purification and characterization of thermostable, protease resistant Bacteriocin active against methicillin resistant Staphylococcus aureus (MRSA)
}

\author{
Asma Ansari ${ }^{1 *}$ (D, Rashida Rahmat Zohra², Omer Mukhtar Tarar ${ }^{3}$, Shah Ali UI Qader ${ }^{4}$ and Afsheen Aman ${ }^{1}$
}

\begin{abstract}
Background: The emergence of serious issues of multidrug resistance in the past few years have enforced the use of bacteriocins for combating infections. Threat posed to public health by various multidrug resistant (MDR) organisms can be resolved by discovering new antimicrobial proteins with broad spectrum of inhibition.

Results: In the current study, Bacteriocin (BAC-IB17) produced by Bacillus subtilis KIBGE-IB17 is found to be effective against different strains of methicillin resistant Staphylococcus aureus (MRSA). The approximate molecular mass of BAC-IB17 is $10.7 \mathrm{kDa}$. This unique bacteriocin is found to be highly thermostable and pH stable in nature. It also showed its stability against various heavy metals, organic solvents, surfactants and proteolytic enzymes. Amino acid profile of BAC-IB17 clearly showed that this protein mainly consists of non-polar and basic amino acids whereas; some acidic amino acids were also detected. Sequence of first 15 amino acid residues obtained from $\mathrm{N}$-terminal sequencing of BAC-IB17 were NKPEALVDYTGVXNS.

Conclusions: The anti-MRSA property of purified bacteriocin may be used to prevent the spread of MRSA infections. Remarkable features of BAC-IB17 suggests its applications in various pharmaceutical and food industries as it can function under a variety of harsh environmental conditions.
\end{abstract}

Keywords: Antibacterial potential, Bacillus subtilis, Bacteriocin purification, Multidrug resistance, Thermostable

\section{Background}

Numerous concerns have been raised against increased bacterial resistance towards effective drugs and become a debated issue all over the world. Now a days, there is an increase consumer demands for the natural antimicrobial compounds to overcome emergence of multidrug resistance. Microorganisms are involved in the production of an astonishing range of natural antimicrobial compounds as their defense mechanism. In the past few years, research on bacteriocins is opening a door of a new age as a new generation of antimicrobials. Therefore, threat posed to public health by multidrug resistant organisms prevalent in the community can be resolved

\footnotetext{
* Correspondence: asansari@uok.edu.pk; asma.ansari@kibge.edu.pk

${ }^{1}$ The Karachi Institute of Biotechnology \& Genetic Engineering

(KIBGE)University of Karachi, 75270, Karachi, Pakistan

Full list of author information is available at the end of the article
}

by the discovery of new antimicrobial proteins with broad spectrum of inhibition.

Methicillin resistant Staphylococcus aureus (MRSA) is an alarming threat of interest that is responsible for either community acquired (CA-MRSA) or health-care-acquired (HA-MRSA) infections. MRSA is involved in several lives threatening human infections as it is resistant to almost all $\beta$-lactam antibiotics and now a days responsible for the emerging cases of MDR [1-5]. The aforesaid problem is persisting not only because of the development of different ways to resist effective antibiotics by multidrug resistant microorganisms however, incessant misuse of antibiotics in human medicines, veterinary and agricultural sectors are also predominantly contributing in this phenomenon. Therefore, for the effective control of MDR organisms, it is imperative to discover and characterize new antibacterial proteins.

(c) The Author(s). 2018 Open Access This article is distributed under the terms of the Creative Commons Attribution 4.0 International License (http://creativecommons.org/licenses/by/4.0/), which permits unrestricted use, distribution, and 
Bacteriocins produced by Gram's positive bacteria exhibited a broad spectrum of inhibition as compared to other bacteriocins.Most of the species from genus Bacillus are generally recognized as safe (GRAS) to produce antimicrobial compounds for the treatment of infections in humans [6-10]. Bacillus subtilis probiotics and their metabolites are promising candidates in biotechnological applications including production of enzymes, amino acids, antifungal and antibacterial substances. All these factors increase the industrial importance of this organism with the reduction in potential risk factors associated with the use of $B$. subtilis in industries. The plasmid borne bacteriocin (BAC-IB17) expressed and secreted by a locally isolated strain of Bacillus subtilis KIBGE-IB17 [GenBank: HQ588347] showed broad spectrum of inhibition against various pathogenic and non-pathogenic strains $[11,12]$. The current study hypothesize that BAC-IB17 are able to suppress the MRSA growth and may be successful as an alternative therapeutic agent to prevent spread of MDR organisms. The aim of the current study was to purify, characterize and to elucidate the properties and the antibacterial potential BAC-IB17 against MDR organisms. Therefore, a pool of effective drugs could be available to overcome the newly emerging drug resistant bacteria.

\section{Methods}

\section{Bacterial strains}

The sensitive strains used in the current study were isolated from clinical, soil and water samples collected from different localities in Karachi, Pakistan and no specific permission was required for the isolation of microbial strains because the isolated strains are indigenous in the local environment and are not endangered or protected species (Table 1). Isolates obtained from primary culture were grown on non-selective agar and identified based on morphological, biochemical characteristics and $16 \mathrm{~S}$ rDNA gene sequencing [13]. For the specific confirmation of MRSA and MSSA, sensitivity test was performed using methicillin and bacitracin. Whereas, Gram's reaction, pigment production, catalase test, coagulase test, oxidase test, citrate utilization, nitrate reduction, growth in $\mathrm{NaCl}$ and sugar fermentation (mannitol and glucose) were also conducted. 16S rDNA gene sequences of MRSA and MSSA were analyzed by similarity search using BLAST (http://www.ncbi.nlm.nih.gov/BLAST/). Percentage identity between the current isolates and the previously reported $16 \mathrm{~S}$ rDNA sequences which were available in the GenBank database was constructed using Clustal-W and MegAlign programmes (Lasergene, DNASTAR Inc., Madison, USA).

Table 1 Inhibitory spectrum of BAC-IB17 against different bacterial strains

\begin{tabular}{|c|c|c|c|c|}
\hline Indicator strains & Source & Temperature $\left({ }^{\circ} \mathrm{C}\right)$ & Incubation time (hrs) & Sensitivity $^{\mathbf{a}}$ \\
\hline Staphylococcus aureus (MRSA) & Clinical (KIBGE-IB23) & 37 & 24 & ++++ \\
\hline Staphylococcus aureus (MSSA) & Clinical (KIBGE-IB24) & 37 & 24 & ++++ \\
\hline Staphylococcus aureus (MSSA) & Water & 37 & 24 & ++++ \\
\hline Staphylococcus aureus (MSSA) & Soil & 37 & 24 & ++++ \\
\hline Staphylococcus aureus (MRSA) & Clinical Isolate & 37 & 24 & +++ \\
\hline Staphylococcus aureus (MRSA) & Clinical Isolate & 37 & 24 & +++ \\
\hline Staphylococcus aureus (MRSA) & Clinical Isolate & 37 & 24 & +++ \\
\hline Enterococcus faecalis & Soil & 37 & 48 & +++ \\
\hline Staphylococcus aureus (MRSA) & Clinical Isolate & 37 & 24 & ++ \\
\hline Staphylococcus aureus (MRSA) & Clinical Isolate & 37 & 24 & ++ \\
\hline Bacillus stearothermophilus & Soil (KIBGE-IB29) & 60 & 24 & ++ \\
\hline Bacillus subtilis & Soil & 37 & 24 & ++ \\
\hline Listeria monocytogenes & ATCC 7644 & 35 & 48 & ++ \\
\hline Staphylococcus epidermidis & Environment & 37 & 24 & ++ \\
\hline Salmonella typhi A & Clinical Isolate & 37 & 24 & + \\
\hline Staphylococcus aureus (MRSA) & Clinical Isolate & 37 & 24 & + \\
\hline Salmonella typhimurium & Clinical Isolate & 37 & 24 & + \\
\hline Escherichia coli & ATCC 8739 & 35 & 18 & + \\
\hline Bacillus licheniformis & Environment (KIBGE-IB2) & 40 & 24 & + \\
\hline Bacillus licheniformis & Soil (KIBGE-IB4) & 40 & 24 & - \\
\hline
\end{tabular}

${ }^{a}$ Key: (-) No Antgonistic Activity; (+) Inhibitory zone diameter within 11-15 mm; (++) Inhibitory zone diameter within 16-20 mm; (+++) Inhibitory zone diameter within 21-25 $\mathrm{mm}$; (++++) Inhibitory zone diameter within $26-30 \mathrm{~mm}$ 


\section{BAC-IB17 production and purification}

Production of BAC-IB17 was augmented by manipulating a variety of physical and chemical parameters [11]. Extracellular bacteriocin was obtained after centrifugation of $24 \mathrm{~h}$ grown culture medium at 35,000 $\times g$ for 15 min at $4{ }^{\circ} \mathrm{C}$. Cell free supernatant containing BAC-IB17 was filtered through $0.22 \mu \mathrm{m}$ filter membrane (Millipore, USA) using a filtration assembly (Sartorius, Germany) under sterile conditions for further studies. Bacteriocin was partially purified by gradient salt precipitation method. Partially purified bacteriocin was desalted using PD-10 desalting column with a cutoff value of $5.0 \mathrm{kDa}$ and filtered using Centricon Ultracel YM-10 and YM-30 centrifugal filter device. Gel permeation chromatography was performed for the purification of the BAC-IB17. All the collected fractions were assayed for antibacterial activity and the fractions that showed anti MRSA activity were pooled and freeze dried [14]. This purified BAC-IB17 was used for further characterization purpose.

\section{Calculation of arbitrary units and minimal inhibitory concentration (MIC)}

The antimicrobial activity of bacteriocin was detected by agar well diffusion method [15]. Two-fold serial dilutions of purified bacteriocin was prepared and the activity was expressed in terms of arbitrary units per milliliter (AU $\mathrm{ml}^{-1}$ ). One arbitrary unit (AU) is defined as the reciprocal of the highest dilution of bacteriocin showing a clear zone of growth inhibition of indicator strain.

For the calculation of arbitrary units of bacteriocin, twofold serial dilutions were prepared in $50.0 \mathrm{mM}$ potassium phosphate buffer (pH-7.0). Each dilution $(100.0 \mu \mathrm{L})$ was placed into the wells on nutrient agar plate which was previously spreaded with the indicator strain. The plate was incubated at $37{ }^{\circ} \mathrm{C}$ for $24 \mathrm{~h}$ and the zone of inhibition was measured in millimeters. Arbitrary units were calculated using the following formula:

Arbitrary Units $(A U / m l)=\frac{\text { Reciprocal of the Highest Dilution }}{\text { Amount of Bacteriocin Used }} \times 1000$

MIC is measured using tube dilution method. Twofold serial dilutions of purified bacteriocin with initial concentration of $0.43 \mathrm{mg} \mathrm{ml}^{-1}$ were prepared in $50.0 \mathrm{mM}$ potassium phosphate buffer ( $\mathrm{pH}-7.0)$. A fixed volume $(100.0 \mu \mathrm{L})$ of standardized inoculum $\left(10^{8} \mathrm{CFUml}^{-1}\right)$ of the indicator organism was incorporated in each dilution tube. The final concentration of bacteriocin preparation is become one-half of the initial concentration in each tube. Tubes were incubated at $37^{\circ} \mathrm{C}$ for $24 \mathrm{~h}$. The tubes were examined for any visible sign of bacterial growth by plate counting method. The highest dilution without bacterial growth is considered as the minimal inhibitory concentration of BAC-IB17. Total protein concentration of the samples was calculated by Lowry's method using bovine serum albumin as standard [16].

\section{Killing kinetics of BAC-IB17}

To determine the killing kinetics of BAC-IB17, indicator strains (logarithmic phase) were harvested by centrifugation and suspended into fresh nutrient broth. BAC-IB17 preparation $\left(80 \mathrm{AU} \mathrm{ml}^{-1}\right)$ with the protein concentration of $0.05 \mathrm{mg} \mathrm{ml}^{-1}$ was added to the indicator organisms $\left(10^{8} \mathrm{CFUml}^{-1}\right)$ and incubated at $37^{\circ} \mathrm{C}$ for $24 \mathrm{~h}$. Samples were drawn at different time intervals and plated on nutrient agar plates to determine the survival rate of each indicator organism. Optical density at $600 \mathrm{~nm}$ of the samples was also measured. Indicator organisms alone were used as a control.

\section{BAC-IB17 characterization Molecular weight estimation}

Tricine SDS-PAGE was performed to determine the approximate molecular weight of the bacteriocin by comparing its electrophoretic mobility with the mobility of standard proteins of known low molecular weight markers (M.W. 6500-66,000 Da; M3913, Sigma-Aldrich). Electrophoresis was carried out according to the method as described by Schägger [17] with some modifications and for the confirmation of the band of interest, gel overlay assay was performed.

\section{Thermal and $\mathrm{pH}$ stability of BAC-IB17}

Different physical and chemical parameters were considered in order to determine the kinetic behavior of BAC-IB17 $\left(0.05 \mathrm{mg} \mathrm{ml}^{-1}\right)$ with respect to its clinical applications. Thermal stability of bacteriocin was performed at various temperatures ranging from $40^{\circ} \mathrm{C}$ to $100^{\circ} \mathrm{C}$ for different time intervals. For $\mathrm{pH}$ stability, bacteriocin was treated with various buffers having different $\mathrm{pH}$ values ranging from 3.0 to 9.0 for $2.0 \mathrm{~h}$ at $37^{\circ} \mathrm{C}$. Sodium citrate buffer (50 mM, pH: 3.0 to 6.0); potassium phosphate buffer ( $50 \mathrm{mM}, \mathrm{pH}: 7.0)$ and TrisHCl buffer ( $50 \mathrm{mM}, \mathrm{pH}$ : 8.0 to 9.0 ) were used. Buffers alone were used as negative controls. After treatments, agar well diffusion assay was performed and plates were incubated at $37^{\circ} \mathrm{C}$ for $24 \mathrm{~h}$ and percent relative activity was calculated. For the determination of storage stability, BAC-IB17 was stored at $-20^{\circ} \mathrm{C}$ for 01 year.

\section{Effect of metal ions, surfactants and organic solvents on $B A C-I B 17$}

All metal ions were used as chloride salts $(1.0 \mathrm{mM}, 5.0$ $\mathrm{mM}$ and $10 \mathrm{mM})$. BAC-IB17 was pre-incubated with metal ions, surfactants and organic solvents before antibacterial activity assay at $37^{\circ} \mathrm{C}$ for $1 \mathrm{~h}$ and the percent relative activity was compared with reference to control. 
Effect of enzymes on antibacterial potential of BAC-IB17

BAC-IB17 was also treated with various enzymes at $37^{\circ} \mathrm{C}$ and $50^{\circ} \mathrm{C}$ up to $24 \mathrm{~h}$ including protease (MP Biomedicals, USA), proteinase-K (Life Technologies, USA), amylase (Sigma-Aldrich, USA), pepsin, lysozyme, ribonuclease A and catalase (Serva, Germany). For this $1.0 \mathrm{~mL}$ of purified bacteriocin with initial concentration of $0.43 \mathrm{mg} \mathrm{ml}^{-1}$ was incubated with equal volume of enzymes with the final concentration of all the enzymes used was $1.0 \mathrm{mg} \mathrm{ml}^{-1}$ and the relative antibacterial activity was calculated using agar well diffusion assay.

\section{Comparison of BAC-IB17with different antibacterial drugs}

The effect of bacteriocin on MRSA was evaluated with reference to different drugs available in the market. For this purpose, different antibiotics including vancomycin, teicoplanin, linezolid, cefepime, ceftriaxone, ertapenem, ampicillin, ciprofloxacin, clindamycin and oxacillin were purchased from the local vendor (Oxoid Ltd., Hampshire, UK) and their minimal inhibitory concentrations (MICs) were compared with the MIC of the BAC-IB17 using agar well diffusion assay. The minimal inhibitory concentration of the BAC-IB17 used in this experiment was $0.05 \mathrm{mg} \mathrm{ml}^{-1}$.

\section{Relative amino acid composition analysis and $\mathrm{N}$-terminal sequencing of $B A C-I B 17$}

Amino acids analysis was performed using O-phthalal dehyde (OPA) derivatization through an amino acid analyzer (Shimadzu LC -10A/C - R7A, USA). Purified bacteriocin was blotted on a polyvinylidenedifloride (PVDF) membrane using a semi-dry blotting device (Thermo Scientific, USA). Electroblotting was performed by the method as described earlier with some modifications [18]. The sample was sent to the protein-sequencing facility at Alta Biosciences Limited (Birmingham, United Kingdom) for the determination of N-terminal sequence. The sample was analyzed directly by using an ABI Procise 491 Protein Sequencer.

All the experiments were performed in triplicate and the results are the mean of all observations with the standard error $\pm 3.0 \mathrm{AU}$.

\section{Results}

\section{Screening and inhibitory spectrum}

Different bacterial strains $(n=40)$ were isolated and screened for antimicrobial activity against Gram's positive and Gram's negative microorganisms. In the current study, various strains of MRSA and MSSA were also isolated and identified. The 16S rDNA gene sequences of highly sensitive strains were deposited in GenBank and received following accession numbers: Methicillin resistant Staphylococcus aureus KIBGE-IB23 [KC465400] and Methicillin Sensitive Staphylococcus aureus KIBGE-IB24
[KC465401]. A phylogenetic tree for both the organisms was constructed and compared with the previously reported sequences available in NCBI GenBank database. $16 \mathrm{~S}$ rDNA gene sequence showed 89 to $100 \%$ identity within the current isolates and the previously reported sequences retrieved from GenBank database. Figure 1 demonstrated the broad antibacterial potential of BAC-IB17 against different organisms using stab and overlay method.

Purification and molecular weight estimation of BAC-IB17 BAC-IB17 was partially purified using $40 \%$ ammonium sulphate saturation and desalted through PD-10 desalting columns with an increase in the arbitrary units, fold purification and specific activity from 2.5 to 5.72 times and 166.29 to $380.95\left(\mathrm{AU} \mathrm{mg}^{-1}\right)$. After passing through Centricon centrifugal filter device (cutoff: 10.0 and 30.0 $\mathrm{kDa}$ ) the antibacterial activity was detected in the retainate and then in filtrate, respectively. Fractions collected from CL-6B column were pooled and concentrated. Final specific activity and fold purification increased from 130 to $186 \mathrm{AU} \mathrm{mg}^{-1}$ and 15.6 to 22.3 times, respectively with maximum arbitrary units of $1505.88 \mathrm{AU}$ $\mathrm{mg}^{-1}$. Tricine SDS-PAGE was also performed after each step of purification, which revealed that the estimated molecular weight of purified BAC-IB17 was approximately $10.7 \mathrm{kDa}$ with the specific activity of band of interest in gel overlay assay (Fig. 2 and b). The arbitrary units and the minimal inhibitory concentration of the purified BAC-IB17 were $80 \mathrm{AU} \mathrm{ml}^{-1}$ and $50 \mu \mathrm{g} \mathrm{ml}^{-1}$, respectively.

\section{BAC-IB17 mode of action}

Killing kinetics revealed that purified BAC-IB17 exhibits a bactericidal mode of action against the tested indicator organisms in a lethal concentration of $80 \mathrm{AU}$ $\mathrm{ml}^{-1}$. For this purpose, the rate of survival of two indicator organisms including MRSA (KIBGE-IB23) and MSSA (KIBGE-IB24) after the treatment with BACIB17 was monitored using plate counting method. In case of MRSA, complete growth reduction was observed in $8.0 \mathrm{~h}$ whereas, for MSSA it was $3.0 \mathrm{~h}$ only. However, for further confirmation of bactericidal mode of action, the regrowth of both the organisms was monitored up to $24 \mathrm{~h}$ (Fig. 3).

\section{Influence of physical and chemical parameters on BAC- IB17}

The influence of temperature, $\mathrm{pH}$ and various metal ions were also detected on the antibacterial potential of BAC-IB17 (Table 2). BAC-IB17 was found to be highly thermostable as it retained $100 \%$ of its antibacterial activity at $60^{\circ} \mathrm{C}$ up to $3.0 \mathrm{~h}$ whereas; only $25 \%$ loss in activity was detected after $4.0 \mathrm{~h}$ of exposure at $80^{\circ} \mathrm{C}$. 


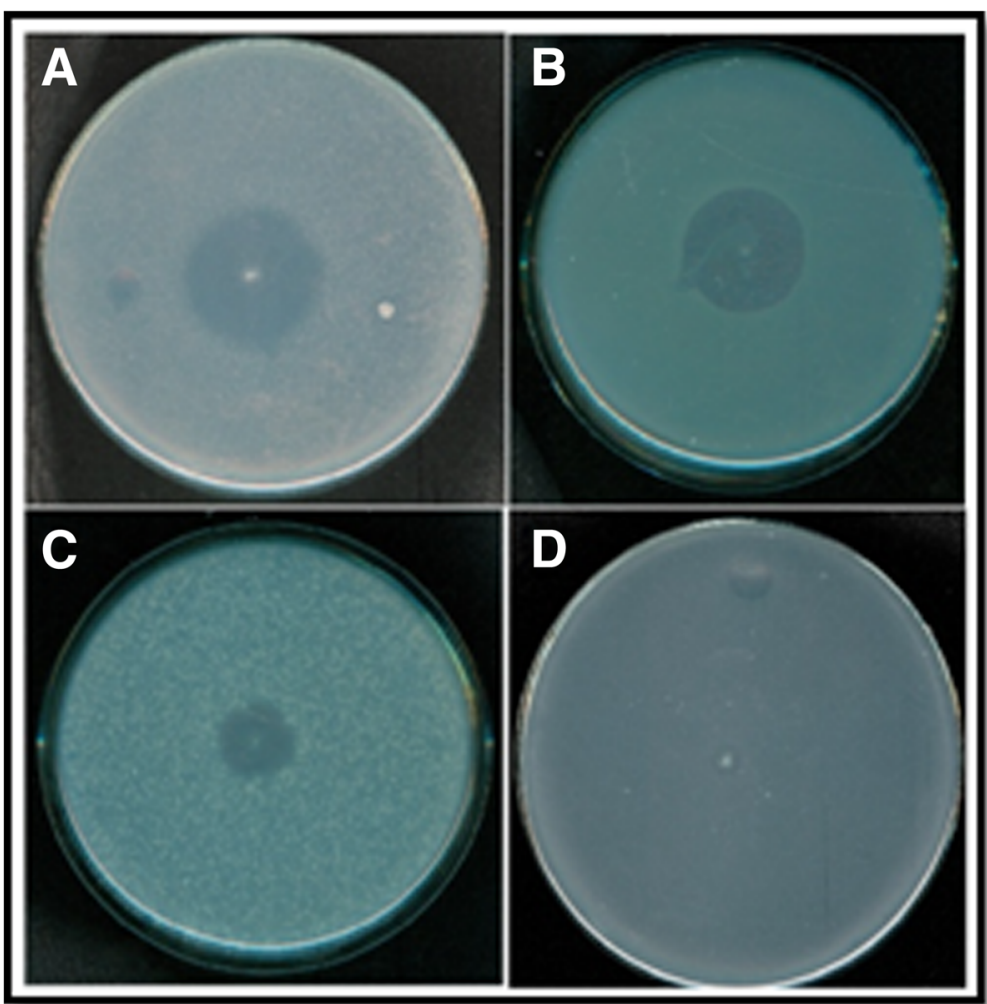

Fig. 1 Antibacterial activity of BAC-IB17 against various microbes by stab and overlay method. a Methicillin resistant Staphylococcus aureus KIBGEIB23; (b) Methicillin sensitive Staphylococcus aureus KIBGE-IB24; (c) Bacillus stearothermophilus KIBGE-IB29; (d: Escherichia coli ATCC 8739. All the strains were grown at $37^{\circ} \mathrm{C}$ for $24 \mathrm{~h}$ on nutrient agar plates except $B$. stearothermophilus which was grown at $55^{\circ} \mathrm{C}$

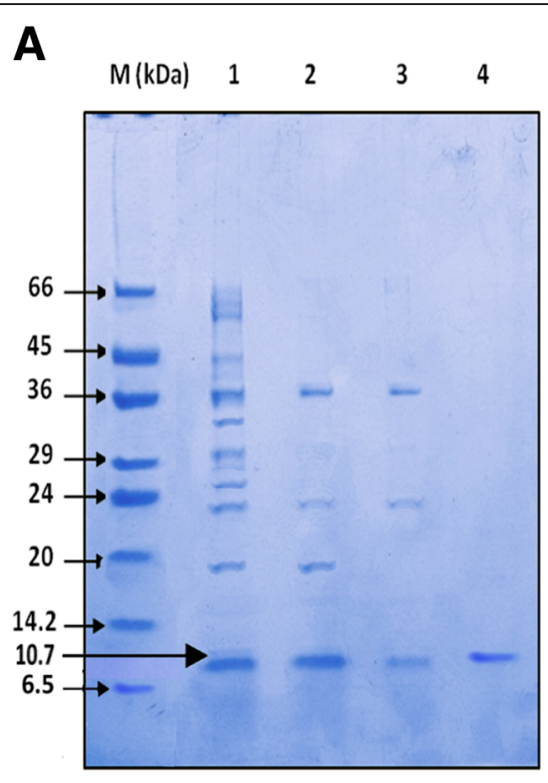

B

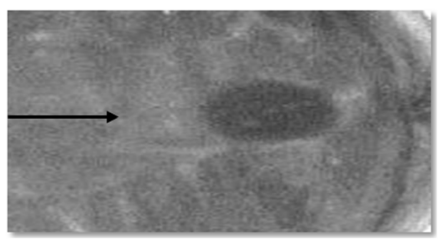

Fig. 2 a SDS-PAGE Profile of BAC-IB17 produced by Bacillus subtilis KIBGE-IB17. Lane M: Low molecular weight markers (6500-66,000, SigmaAldrich, USA). Lane 1: BAC-IB17 precipitates after $\left(\mathrm{NH}_{4}\right)_{2} \mathrm{SO}_{4}$ saturation. Lane 2: BAC-IB17 precipitates after passing through PD-10 desalting column. Lane 3: BAC-IB17 precipitates after passing through Centricon ${ }^{\oplus}$ ultrafilter device. Lane 4: Purified and concentrated BAC-IB 17 after passing through Sepahrose-CL6B column. b Gel Overlay Assay of Band of interest against MRSA 

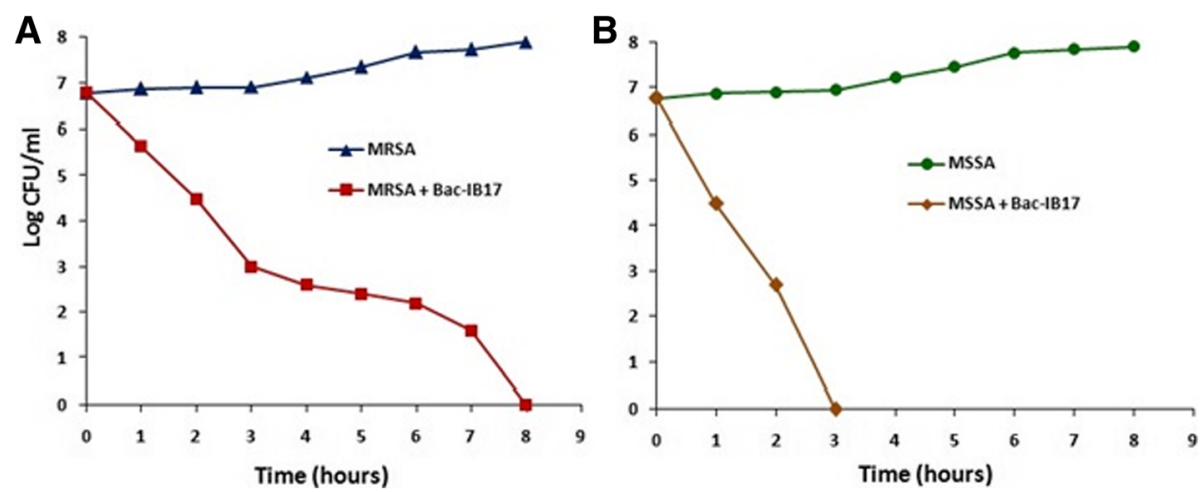

Fig. 3 Bactericidal effect of BAC-IB17 on the growth and survival of MRSA and MSSA. a Methicillin resistant Staphylococcus aureus; (b) Methicillin sensitive Staphylococcus aureus

Table 2 Antibacterial activity of BAC-IB17 against methicillin resistant Staphylococcus aureus after treatment with various physical and chemical parameters

\begin{tabular}{|c|c|c|c|c|c|c|c|c|c|}
\hline \multirow{2}{*}{$\begin{array}{l}\text { Treatment } \\
\text { Control }\end{array}$} & \multicolumn{4}{|c|}{$\%$ Relative Antibacterial Activity } & Treatment & \multicolumn{4}{|c|}{ Antibacterial Activity $\left(\mathrm{AU} \mathrm{ml}^{-1}\right)$} \\
\hline & \multicolumn{4}{|l|}{100} & Control & \multicolumn{4}{|l|}{80} \\
\hline \multirow[t]{2}{*}{ a. Temperature $\left({ }^{\circ} \mathrm{C}\right)$} & \multicolumn{9}{|c|}{ Exposure Time (hours) } \\
\hline & 1.0 & 2.0 & 3.0 & 4.0 & d. Surfactants ${ }^{b}$ & & & & \\
\hline 40 & 100 & 100 & 100 & 100 & & & & & \\
\hline 60 & 100 & 100 & 100 & 96 & Tween 20 (10 mM) & 160 & & & \\
\hline 80 & 97 & 83 & 80 & 75 & Tween 80 (10 mM) & 160 & & & \\
\hline 100 & 70 & 50 & nil & nil & EDTA (100 mM) & 160 & & & \\
\hline \multirow[t]{2}{*}{ b. $\mathrm{pH}$} & \multicolumn{4}{|c|}{ Exposure Time (minutes) } & SDS (01 mM) & 160 & & & \\
\hline & 15.0 & 30.0 & 60.0 & 120.0 & Triton X-100 (0.25 mM) & nil & & & \\
\hline 5.0 & nil & nd & nd & nd & e. Organic Solvents ${ }^{c}$ & & & & \\
\hline 6.0 & 60 & 60 & 60 & 60 & & & & & \\
\hline 7.0 & 100 & 100 & 100 & 100 & DMSO (100 mM) & 160 & & & \\
\hline 8.0 & 80 & 80 & 80 & 80 & Ethanol (05 mM) & 160 & & & \\
\hline 9.0 & 75 & 75 & 75 & 75 & Methanol (100 mM) & 80 & & & \\
\hline \multirow[t]{2}{*}{ c. Metal lons ${ }^{a}$} & \multicolumn{4}{|c|}{ Concentration (mM) } & Formaldehyde (20 mM) & 80 & & & \\
\hline & 1.0 & 5.0 & 10.0 & & Chloroform (100 mM) & 40 & & & \\
\hline $\mathrm{Ba}^{+2}$ & 100 & 100 & 100 & & Isopropanol (100 mM) & 20 & & & \\
\hline $\mathrm{Cu}^{+2}$ & 100 & nil & nd & & f. Enzymes ${ }^{d}$ & $37^{\circ} \mathrm{C}$ & & $50^{\circ} \mathrm{C}$ & \\
\hline $\mathrm{Mn}^{+2}$ & 100 & 90 & 90 & & & $02 \mathrm{~h}$ & $24 \mathrm{~h}$ & $02 \mathrm{~h}$ & $24 \mathrm{~h}$ \\
\hline $\mathrm{Cs}^{+2}$ & 100 & 90 & 90 & & Protease $(0.5 \mathrm{U})$ & 80 & 40 & 80 & 40 \\
\hline $\mathrm{Ca}^{+2}$ & 100 & 100 & 100 & & Proteinase K (20.0 U) & 80 & 40 & 80 & 40 \\
\hline $\mathrm{Mg}^{+2}$ & 95 & 95 & 90 & & Pepsin $(15.0 \cup)$ & 80 & 40 & 80 & 40 \\
\hline $\mathrm{Ni}^{+2}$ & 80 & 80 & 80 & & Lysozyme (150,000 U) & 40 & nil & 40 & nil \\
\hline $\mathrm{Zn}^{+2}$ & 70 & 30 & nil & & Amylase (30.0 U) & 40 & nil & 40 & nil \\
\hline $\mathrm{CO}^{+2}$ & 60 & nil & nd & & Ribonuclease A (90.0 U) & 80 & 80 & 80 & 80 \\
\hline $\mathrm{Hg}^{+2}$ & nil & nd & nd & & Catalase $(11,000 \mathrm{U})$ & 80 & 80 & 80 & 80 \\
\hline
\end{tabular}

nd Not determined

nil No antibacterial activity

${ }^{a}$ Metal ions used as chloride salts

${ }^{b}$ None of the surfactants alone (-ve control) in the above mentioned concentration inhibited the indicator strain except Triton X-100

${ }^{c}$ None of the organic solvents alone (-ve control) in the above mentioned concentration inhibited the indicator strain

${ }^{d}$ Final Concentration of each enzyme: $1.0 \mathrm{mg}$ 
However, BAC-IB17 retained $50 \%$ of its activity at a broad range of $\mathrm{pH}$. At acidic $\mathrm{pH}$ value ( $\mathrm{pH}$ 5.0) the antibacterial activity was completely lost however, $60 \%$ of its antibacterial activity was detected at $\mathrm{pH}$ 6.0. Table 2 demonstrated that $100 \%$ relative activity was observed at physiological $\mathrm{pH}$ and bacteriocin was stable at alkaline $\mathrm{pH}$ values as compared to the acidic site. Moreover, the effect of $\mathrm{pH}$ on this bacteriocin was independent of the exposure time. It was also observed that upon long-term storage at $-20^{\circ} \mathrm{C}$, no loss in antibacterial activity of BAC-IB17 was detected even after 01 year of storage (data not shown). BAC-IB17 was also stable in the presence of various metal ions of alkaline-earth cation series. Metal Ions exhibited stabilizing effect on antibacterial potential of bacteriocin in low concentration whereas, $\mathrm{Co}^{2+}$ and $\mathrm{Hg}^{2+}$ completely inhibited the antibacterial activity.

Antibacterial activity of BAC-IB17 was increased in the presence of various surfactants. Two-fold increase in the activity was observed after treatment with Tween 20, Tween 80, EDTA and SDS. However, Triton X-100 completely inhibited the indicator strain itself even at low concentration $(0.05 \mathrm{mM})$ and produced no effect on the antibacterial activity of BAC-IB17. Among various organic solvents tested, DMSO and ethanol exhibited an accelerating effect whereas, methanol and formaldehyde stabilized the inhibitory effect of this bacteriocin. Chloroform and isopropanol suppressed its antibacterial effect. Although bacteriocins are generally sensitive to proteolytic enzymes, resistance of some low molecular weight peptides to various proteases was not an unusual feature. Therefore, the effect of proteolytic enzymes on BAC-IB17 revealed that BAC-IB17 was completely resistant to various proteolytic enzymes up to $2.0 \mathrm{~h}$ but $50.0 \%$ loss in antibacterial activity was observed when the exposure time was extended up to $24 \mathrm{~h}$ (Fig. 4). While in case of lysozyme and amylase, complete loss in antibacterial activity was detected after $24 \mathrm{~h}$. Ribonuclease A and catalase had no profound effect on BAC-IB17 (Table 2).

\section{MICs of BAC-IB17 and different antibacterial drugs}

In order to determine the clinical effectiveness of BAC-IB17, its efficacy was compared with several known anti-MRSA and broad-spectrum drugs. It was observed that indigenously isolated MRSA (KIBGE-IB23) was resistant to some commercially available broad-spectrum antibiotics including ciprofloxacin, oxacillin and ertapenem however, sensitive to BAC-IB17 in the minimal inhibitory concentration of $50 \mu \mathrm{g} \mathrm{ml}^{-1}$. Furthermore, MICs of other drugs were also determined against indigenously isolated MRSA (Table 3).

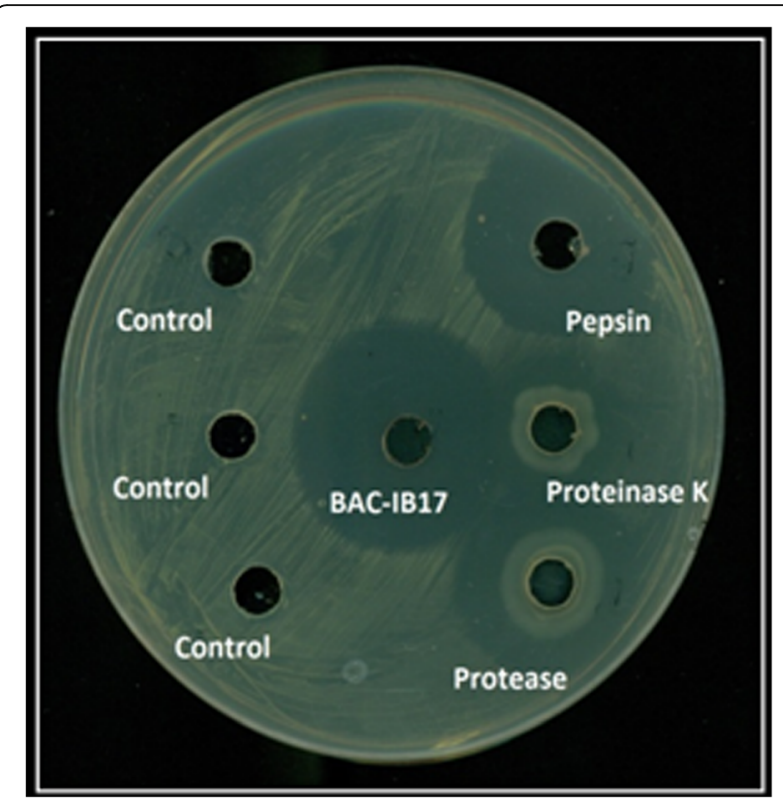

Fig. 4 Effect of different proteolytic enzymes on the antibacterial activity of BAC-IB17. Control: all the respective enzymes alone were used as a negative control

\section{Amino acid analysis and $\mathrm{N}$-terminal sequencing}

Compositional amino acids analysis of BAC-IB17 represented a unique distribution profile based on only thirteen amino acids that were identified using standard amino acid solution (Sigma) with reference to retention time. Compositional analysis of amino acid showed that BAC-IB17 consist of both polar (Arginine, Aspartc acid, Glutamic acid, Threonine, Lysine and Serine) and non-polar (Alanine, Methionine, Leucine, Glycine, Tyrosine, Valine and Proline) amino acids. Furthermore, the $\mathrm{N}$-terminal sequence identification of first 15 residues of

Table 3 Minimal Inhibitory Concentrations (MICs) of BAC-IB17 and commercially available antibiotics against Methicillin Resistant Staphylococcus aureus (MRSA)

\begin{tabular}{ll}
\hline Antibacterial Drugs & Minimal Inhibitory Concentrations $\left(\mu \mathrm{gL}^{-1}\right)$ \\
\hline BAC-IB17 & 50 \\
Cefepime & 30 \\
Linezolid & 15 \\
Ampicillin & 10 \\
Vancomycin & 2 \\
Ceftriaxone & 2 \\
Teicoplanin & 1 \\
Clindamycin & 1 \\
Ertapenem & $R$ \\
Ciprofloxacin & $\mathrm{R}$ \\
Oxacillin & $\mathrm{R}$
\end{tabular}

Key: $R$ Resistant 
pure BAC-IB17 was revealed that this bacteriocin constitutes a unique sequence: $\mathrm{NH}_{2}$-Asn-Lys-Pro-Glu-Ala-Leu-Val-Asp-Tyr-Thr-Gly-Val-X-Asn-Ser

(NKPEALVDXTGVXNS). Whereas; $\mathrm{X}$ indicates an amino acid for which the identity could not convincingly be established [TrEMBL/UniProtKB/SwissProt database: COHJE5].

\section{Discussion}

In the past few years the emerging cases of multidrug resistance due to the overuse and misuse of antibiotics has enforced the use of new antimicrobials for combating infections. Threat posed to public health by various multidrug resistant (MDR) organisms can be resolved by discovering new antimicrobials with possibility to antimicrobial resistance. The current study suggests that BAC-IB17 can be used as an alternative therapeutic agent in the prevention and treatment of infections caused by MRSA.

Bacteriocin BAC-IB17 was obtained after several steps of purification. After purification, the understanding of biochemical nature and kinetic behavior of bacteriocin will be significantly assisted in its classification. For this different physicochemical parameters were considered for the characterization of BAC-IB17. Bacteriocins have wide range of molecular weight therefore; gradient system using tricine SDS-PAGE was selected for the determination of molecular weight of BAC-IB17 and the estimated molecular weight was $10.7 \mathrm{kDa}$. Several other bacteriocins have also been separated using tricine SDS-PAGE system including a broad spectrum bacteriocin known as paracin-1.7 $(11.0 \mathrm{kDa})$ produced by Lactobacillus paracasei HD1.7, a new bacteriocins Bacthuricin F103 (11.0 kDa), entomocin 9 (12.4 kDa) from B. thuringiensis and Bac $14 \mathrm{~B}(20 \mathrm{kDa})$ from Bacillus subtilis [19-22]. Killing kinetics was performed to determine the bactericidal and/or bacteriostatic effect against sensitive strains used. Results suggests that BAC-IB17 has a bactericidal mode of action which could be due to the increase in the permeability of the cytoplasmic membrane of the indicator strains that allows the release of hydrophilic molecules from the pore complexes resulting in cell death. [23, 24].

BAC-IB17 was found to be highly stable under different physicochemical conditions. Unambiguous reason for the thermal stability of BAC-IB17 is unknown however; there could be many factors responsible in providing stability to proteins at higher temperatures. High concentration of proline residues, salt bridges, hydrogen bonds and polar surface residues can reduce the risk of instability of any protein at elevated temperatures therefore similar factors might be involved in providing thermal stability to BAC-IB17. These factors not only stabilize the proteins but are also responsible for regulating its kinetics at higher temperatures [25]. The stability of a bacteriocin against various metal ions might be due to the induction of conformational changes in the protein structure, as some metal ions worked as cofactors and rendered proteins stability in soluble form [26]. However in case of $\mathrm{Co}^{2+}$ and $\mathrm{Hg}^{2+}$, the complete loss of antibacterial potential of BAC-IB17 might be due to the blockage of active sites. Furthermore, surfactants accelerated the effect of bacteriocin, normally surfactants unfold proteins by affecting three-dimensional confirmations of proteins and they can also increase the solubility of various proteins due to which the activity of the protein enhances [27]. On the contrary, different organic solvents exerted both the accelerating and the suppressing effect on BAC-IB17. Both these effects could be due to the changes in the conformational structure of this protein as a result of modifications in non-covalent interactions. Stability of BAC-IB17 in the presence of organic solvents could be supportive in a manner that most of the organic solvents are commonly used in preparation of stock solutions for various drugs specifically DMSO. In this perception, BAC-IB17 could be a plausible candidate for the treatment of skin infections caused by various strains of MRSA. Resistance of BAC-IB17 to various proteases was not an unusual feature as some low molecular weight peptides were also found to be resistant to proteolytic enzymes [28]. This effect may be due to the presence of cyclic peptides containing unusual amino acids at the active site of bacteriocin [29]. In case of lysozyme and amylase, BAC-IB17 completely lost its antibacterial activity suggesting that there could be some glycosidic moieties present in BAC-IB17 which may possibly responsible for its biological activity. Similar studies on sublancin (glycopeptides) also showed that glycosylation is essential for its antibacterial activity [30]. Another bacteriocin produced by Lactobacillus curvatus SE1 was reported containing some carbohydrate moiety essential for its activity as its activity decreases in the presence of amylolytic enzymes [31]. However, Ribonuclease A and catalase have no profound effect on BAC-IB17. When the MIC of BAC-IB17 was compared with the MICs of other anti-MRSA drugs, it was observed that the MICs of the commercially available drugs are low as compared to the MIC of BAC-IB17. Due to the continuous increased in the drug resistance, it is suggested that BAC-IB17 could be a better alternative antimicrobial agent to treat MRSA infections as it is naturally isolated from a microorganism.

Amino acid compositional analysis revealed presence of proline; a distinctive cyclic amino acid mainly present in thermostable proteins and responsible for the resistance of proteins against high temperatures. The comparison of the alignment of $\mathrm{N}$-terminal amino acid sequence of BAC-IB17 with reference to other bacteriocins revealed 
that no homology exists with the already existing sequence of bacteriocins from various Bacillus species. Therefore, it is concluded that BAC-IB17 is a novel bacteriocin. This dissimilarity could be due to the presence of inconsistent amino acid sequences of different bacteriocins because one bacterium can produce multiple bacteriocins at a time.

\section{Conclusions}

Keeping in view, the current data of the BAC-IB17 with reference to its biochemical properties and the sequence, it is concluded that the BAC-IB17 does not belong to the class I, II and III as proposed by Abriouel et al. [32]. As it is thermostable in nature and contain some glycosidic moiety responsible for its activity, may be it belongs to Class IV of the bacteriocin [33, 34]. Continuous research on diversified bacteriocins will increase their applications in the health and microbial control alternatives [35]. After reviewing potential properties of BAC-IB17, its plausible applications could be in various pharmaceutical and food industries as it can function under a variety of harsh environmental conditions.

\section{Abbreviations}

AU: Arbitrary units; CFU: Colony forming units; DMSO: Dimethyl sulfoxide; MDR: Multidrug resistance; MRSA: Methicillin resistant Staphylococcus aureus; MSSA: Methicillin sensitive Staphylococcus aureus; SDS: Sodium dodecyl sulphate; UV: Ultra violet

\section{Acknowledgements}

The authors gratefully acknowledge the financial support from KIBGE, University of Karachi, Karachi, Pakistan.

\section{Funding}

This research work was funded by KIBGE, University of Karachi, Karachi, Pakistan

\section{Availability of data and materials}

All data generated or analyzed during this study have been included in this published article and further information will provide on requests.

\section{Authors' contributions}

A.A. carried out the major experimental work and interpretation of data; R.R.Z. participated in the analytical analysis; O.M.T. performed the amino acid analysis; S.A.Q. reviewed the final manuscript; A.A. supervised in acquisition of laboratory data and finalizing the manuscript. All authors have read and approved the final manuscript.

\section{Ethics approval and consent to participate}

This study was approved by Institutional Ethical Committee (IEC) KIBGE, University of Karachi, Karachi, Pakistan for the isolation of bacteria from clinical samples. Bacterial isolates were collected from pathological laboratory that already have written informed consent from the participants. The present study did not involve human and animals.

\section{Consent for publication}

Not applicable.

\section{Competing interests}

The authors declare that they have no competing interests.

\section{Publisher's Note}

Springer Nature remains neutral with regard to jurisdictional claims in published maps and institutional affiliations.

\section{Author details}

The Karachi Institute of Biotechnology \& Genetic Engineering (KIBGE)University of Karachi, 75270, Karachi, Pakistan. ${ }^{2}$ Jinnah University for Women, Karachi, Pakistan. ${ }^{3}$ Food and Marine Resources Research Centre, Pakistan Council of Scientific \& Industrial Research (PCSIR), Laboratories Complex Karachi, 75280, Karachi, Pakistan. ${ }^{4}$ Department of Biochemistry, University of Karachi, 75270, Karachi, Pakistan.

Received: 13 November 2017 Accepted: 13 November 2018

Published online: 22 November 2018

\section{References}

1. Jensen SO, Lyon BR. Genetics of antimicrobial resistance in Staphylococcus aureus. Future Microbiol. 2009;4:565-82.

2. Kuo $\mathrm{S}$, et al. Comparison of microbiological and clinical characteristics based in SCCmec typing in patients with community-onset methicillinresistant Staphylococcus aureus (MRSA) bacteraemia. Int J Antimicrob Agents. 2012;39:22-6.

3. Tacconelli E, De Angelis G, Cataldo MA, Pozzi E, Cauda R. Does antibiotic exposure increase the risk of methicillin-resistant Staphylococcus aureus (MRSA) isolation? A systematic review and meta-analysis. J Antimicrob Chemother. 2008:61:26-38

4. Ogata $\mathrm{K}$, et al. Commercially distributed meat as a potential vehicle for community-acquired methicillin-resistant Staphylococcus aureus. Appl Environ Microbiol. 2012;78:2797-802.

5. Shaikh S, Fatima J, Shakil S, Rizwi SMD, Kamal MA. Antibiotic resistance and extended spectrum beta-lactamase: types, epidemiology and treatment. Saudi J Biol Sci. 2015;22:90-101.

6. Gillor O, Etzion A, Riley MA. The dual role of bacteriocins as anti- and probiotics. Appl Microbiol Biotechnol. 2008;81:591-606.

7. Elshaghabee FM, Rokana N, Gulhane RD, Sharma C, Panwar H. Bacillus as potential probiotics: status, concerns, and future perspectives. Front Microbiol. 2017:8:1490

8. Fijan S. Microorganisms with claimed probiotic properties: an overview of recent literature. Int J Environ Res Public Health. 2014;11:4745-67.

9. Martirani L, Varcamonti M, Naclerio G, De-Felice M. Purification and partial characterization of bacillocin 490, a novel bacteriocin produced by a thermophilic strain of Bacillus licheniformis. Microb Cell Factories. 2002;1:1-5.

10. Cladera-Olivera F, Caron GR, Brandelli A. Bacteriocin-like substance production by Bacillus licheniformis strain P40. Lett Appl Microbiol. 2004;38:251-6.

11. Ansari A, Aman A, Siddiqui NN, lqbal S, Qader SA. Bacteriocin (BAC-IB17): screening, isolation and production from Bacillus subtilis KIBGE-IB17. Pak J Pharm Sci. 2012;25:195-201.

12. Ansari A, Siddiqui NN, Ghani M, Aman A, Qader SA. Plasmid borne BACIB17: localization of a potential antibacterial positive marker (bact) encoded broad inhibitory spectrum bacteriocin. Pak J Pharm Sci. 2015;28:1331-5.

13. Holt JG, Krieg NR, Sneath PHA, Staley JT, William ST. In: Williams WA, editor. In Bergey's manual of determinative bacteriology, vol. 787. 9th ed. Baltimore: Wavely Company; 1994.

14. Ansari A, Pervez S, Javed U, Abro MI, Nawaz MA, Qader SAU, Aman A. Characterization and interplay of bacteriocin and exopolysaccharidemediated silver nanoparticles as an antibacterial agent. Int J Biol Macromol. 2018;115:643-50.

15. Tagg JR, McGiven A. Assay system of bacteriocins. Appl Microbiol. 1971;21:943.

16. Lowry $\mathrm{OH}$, Roserough NJ, Farr AL, Randall RJ. Protein measurement with the Folin phenol reagent. J Biol Chem. 1951;193:265-75.

17. Schägger H. Tricine-SDS-PAGE. Nat Protoc. 2006;1:16-22.

18. Matsuidaira P. Sequence from picomole quantities of proteins electro blotted on to polyvinylidenedifluoride membranes. J Biol Chem. 1987;262: 10035-8.

19. Ge J, Ping W, Song G, Du C, Ling H, Sun X, Gao Y. Paracin 1.7, a bacteriocin produced by Lactobacillus paracasei HD1.7 isolated from Chinese cabbage sauerkraut, a traditional Chinese fermented vegetable food. Wei Sheng Wu Xue Bao. 2009;49:609-19.

20. Kamoun F, Fquira IB, Hassen NB, Mejdoub H, Lereclus D, Jaoua S. Purification and characterization of a new Bacillus thuringiensis bacteriocin active against Listeria monocytogenes, Bacillus cereus and Agrobacterium tumefaciens. Appl Biochem Biotechnol. 2011;165:300-14.

21. Cherif A, Chehimi S, Limem F, Hansen BM, Hendriksen NB, Daffonchio D, Boudabous A. Detection and characterization of the novel bacteriocin 
entomocin 9, and safety evaluation of its producer, Bacillus thuringiensis ssp. entomocidus HD9. J Appl Microbiol. 2003;95:990-1000.

22. Hammami I, Jaouadi B, Bacha AB, Rebai A, Bejar S, Nesme X, Rhouma A. Bacillus subtilis bacteriocin bac $14 \mathrm{~B}$ with a broad inhibitory spectrum: purification, amino acid sequence analysis, and physicochemical characterization. Biotechnol Bioprocess Eng. 2012;17:41-9.

23. Gonzalez B, Glaasker E, Kunji E, Driessen A, Suarez JE, Konings WN. Bactericidal mode of action of plantaricin C. Appl Environ Microbiol. 1996;62:2701-9.

24. Gálvez A, Valdivia E. Martínez-Bueno, M. and Maqueda, M. induction of autolysis in Enterococcus faecalis S-47 by peptide AS-48. J Appl Bacteriol. 1990;69:406-13.

25. Kumar S, Tsai CJ, Nussinov R. Factors enhancing protein thermostability. Protein Eng. 2000;13:179-91.

26. Benzaghou I, Bougie I, Bisaillon M. Effect of metal ion binding on the structural stability of the hepatitis C virus RNA polymerase. J Biol Chem. 2004;279:49755-61.

27. Ivanova I, Kabadjova P, Pantev A, Danova S, Dousset X. Detection, purification and partial characterization of novel bacteriocin substance produced by Lactococcus lactis subsp, lactis B14 isolated from BozaBulgarian traditional cereal beverage. Biocatalysis Vestnik Moskov Univ Kimia. 2000:41:47-53.

28. Singh PK, Sharma S, Kumari A, Singh SK. A non-pediocin low molecular weight antimicrobial peptide produced by Pediococcus pentosaceus strain IE-3 shows increased activity under reducing environment. BMC Microbiol. 2014; 14:226

29. von Döhren H. In Genetics and biochemistry of antibiotic production. In: Vining LC, Stuttard C, editors. Peptides. Newton MA: ButterworthHeinemann; 1995. p. 129-17.

30. Oman TJ, Boettcher JM, Wang H, Okalibe XN, van der Donk WA. Sublancin is not a lantibiotic but an S-linked Glycopeptide. Nat Chem Biol. 2011:78-80.

31. Koo KS, Ju LE, Young PK, Ki JH. Bacteriocin produced by Lactobacillus curvatus SE1 isolated from kimchi. J Microbiol Biotechnol. 1998:588-94.

32. Abriouel H, Franz CMAP, Omar NB, G'alvez A. diversity and applications of Bacillus bacteriocins. FEMS Microbiol Rev. 2011;35:201-32.

33. Heng NCK, Tagg JR. What's in a name? Class distinction for bacteriocins. Nat Rev Microbiol. 2006;4:160.

34. Heng, N.C.K., Wescombe, P.A., Burton, J.P., Jack, R.W. and Tagg, J.R. in The diversity of Bacteriocins produced by Gram-positive bacteria. Bacteriocins Ecology and Evolution. eds Riley, M.A. \& Chavan, M.A. 2007. 45-92. Springer, Heidelberg, Germany.

35. Salazar-Marroquín EL, Galán-Won L, Moreno-Medina VR, Reyes-López MA, Pereyra-Alférez B. Bacteriocins synthesized by Bacillus thuringiensis: generalities and potential applications. Rev Med Microbiol. 2016;27:95-101.

Ready to submit your research? Choose BMC and benefit from:

- fast, convenient online submission

- thorough peer review by experienced researchers in your field

- rapid publication on acceptance

- support for research data, including large and complex data types

- gold Open Access which fosters wider collaboration and increased citations

- maximum visibility for your research: over $100 \mathrm{M}$ website views per year

At $\mathrm{BMC}$, research is always in progress.

Learn more biomedcentral.com/submissions 